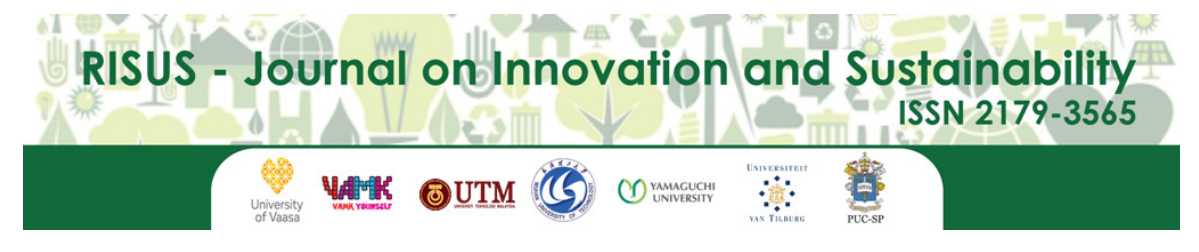

RISUS - Journal on Innovation and Sustainability volume 8 , número 4 - 2017

ISSN: $2179-3565$

Editor Científico: Arnoldo José de Hoyos Guevara Editora Assistente: Lívia Lopes Aguiar

Avaliação: Melhores práticas editoriais da ANPAD

\title{
ENVIRONMENTAL CONSERVATION ACTIONS INFLUENCING INDUSTRIAL COMPETITIVENESS AND INNOVATION: THEORETICAL-PRACTICAL FINDINGS
}

\author{
Ações de Conservação Industrial influenciando a Competitividade e a Inovação Industrial: \\ Conclusões Teórico-práticas.
}

\author{
Diogo José Horst ${ }^{1}$, Pedro Paulo Andrade Junior ${ }^{2}$, Julia Hornick ${ }^{3}$ \\ ${ }^{1}$ Universidade Tecnológica Federal do Paraná, Brazil \\ ${ }^{2}$ Universidade Federal de Santa Catarina,Brazil \\ ${ }^{3}$ Universidade do Estado de Santa Catarina \\ E-mail: diogohorst@hotmail.com; pp.andradej@ufsc.br; \\ juliahornick@hotmail.com
}

\begin{abstract}
The aim of this study was to understand if environmental conservation actions influence industrial competitiveness and innovation. A systematic review was performed in the Scopus ${ }^{\circledR}$ database searching for studies published between 2009 and 2016, in order to obtain the knowledge base related to the topic. Additionally, a questionnaire grounded on literature was applied to multisector group of 15 medium and large Brazilian companies with ISO-14000 certification. The results showed that in practice companies recognize that industrial environmental conservation actions have influence on competitiveness and innovation when companies adopt a conscious selection of materials for development of new products without environmental risks or impacts, as well as through continued improvements, innovation of company management system, processing innovations to meet environmental requirements allowing increasing their operational efficiency, processing innovations meeting environmental requirements allowing increasing its productivity, revenue generation with recyclables or wastes, and non-generation of exporting barriers, resulting in costs and losses reduction, thereby increasing the company image in market, thus practical results supported the theoretical basis grounded by Porter.
\end{abstract}

Keywords: Industrial and Environmental Management; Competitiveness; Innovation; Industrial Ecology; Sustainable Development.

Recebido em: 12/09/2017

Aceito em: 24/12/2017 


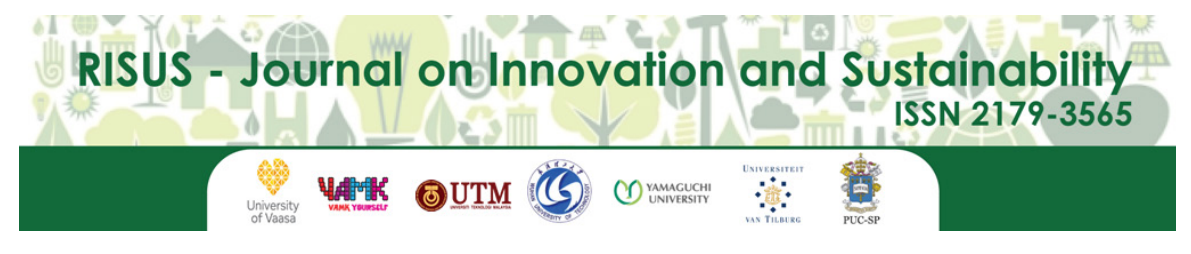

RISUS - Journal on Innovation and Sustainability volume 8 , número 4 - 2017

ISSN: $2179-3565$

Editor Científico: Arnoldo José de Hoyos Guevara Editora Assistente: Lívia Lopes Aguiar

Avaliação: Melhores práticas editoriais da ANPAD

\title{
ENVIRONMENTAL CONSERVATION ACTIONS INFLUENCING INDUSTRIAL COMPETITIVENESS AND INNOVATION: THEORETICAL-PRACTICAL FINDINGS
}

\author{
Ações de Conservação Industrial influenciando a Competitividade e a Inovação Industrial: \\ Conclusões Teórico-práticas.
}

Diogo José Horst ${ }^{1}$, Pedro Paulo Andrade ${ }^{2}$, Junior, Julia Hornick ${ }^{3}$

1 Universidade Tecnológica Federal do Paraná, Brazil

2 Universidade Federal de Santa Catarina,Brazil

3 Universidade do Estado de Santa Catarina

E-mail: diogohorst@hotmail.com; pp.andradej@ufsc.br;

juliahornick@hotmail.com

\begin{abstract}
Resumo: O objetivo deste estudo foi entender se as ações de conservação ambiental influenciam a competitividade e a inovação industrial. Uma revisão sistemática foi realizada no banco de dados Scopus ${ }^{\circledR}$ pesquisando estudos publicados entre 2009 e 2016, para obter a base de conhecimento relacionada ao tema. Além disso, um questionário baseado em literatura foi aplicado ao grupo multisectorial de 15 empresas brasileiras de médio e grande porte com certificação ISO-14000. Os resultados mostraram que na prática as empresas reconhecem que as ações industriais de conservação ambiental têm influência na competitividade e na inovação quando as empresas adotam uma seleção consciente de materiais para o desenvolvimento de novos produtos sem riscos ou impactos ambientais, bem como através de melhorias contínuas, inovação do sistema de gerenciamento de empresas, processando inovações para atender aos requisitos ambientais, permitindo aumentar sua eficiência operacional, processando inovações que atendem aos requisitos ambientais, permitindo aumentar sua produtividade, geração de receita com materiais recicláveis ou resíduos e barreiras de exportação não geradoras, resultando em redução de custos e perdas, aumentando assim a imagem da empresa no mercado, os resultados práticos apoiam a base teórica fundamentada por Porter.
\end{abstract}

Palavras-chave: Gestão Industrial e Ambiental; Competitividade; Inovação; Ecologia Industrial; Desenvolvimento sustentável.

\author{
Recebido em: 12/09/2017
}

Aceito em: 24/12/2017 


\section{INTRODUCTION}

On the one hand, growing levels of global industrialization have benefited society in terms of both financial and social development. On the other hand, this growth has triggered serious concerns due to the environmental losses caused by industries and the secondary sector as a whole (transformation). Consequently, efforts have been made by several agents of society to mitigate expansion of the observed environmental damages.

In recent decades, the adoption of environmental conservation actions by companies has been encouraged and regulated by governmental and nongovernmental agents. Furthermore, corporate environmental conservation actions are now considered a key to helping promoting sustainable development.

The degradation of environmental resources has occurred mainly in the following ways: (i) consumption of natural resources, such as uncontrolled devastation of forests and unconscious use of water; (Ii) the emission of pollutant and toxic gases that are harmful to the atmosphere and to living beings, and (iii) the inadequate disposal of solid wastes and effluents (Andrade et al., 2000; Vachon \& Klassen, 2008; Seiffert 2011).

In a less direct but no less shocking way, the high consumption of natural resources also occurs through the electric energy consumed by the industries, since for the resources can be used such as water (hydroelectric), wood (thermoelectric), among others (Van Bellen, 2006). In this way, the energy efficiency of industrial processes has also entered the agenda of environmental concern of the last decades (Costa, 2002). Therefore, the ways in which the activities of the transformation sector will influence the environment will depend specifically on the activities and processes in question (Almeida, 2006; Eidat et al., 2008).

The environmental conservation actions can be described as a systemic view of the interaction between industrial systems and natural systems, (i) through the study of material and energy flows in industrial systems; (ii) a shift from linear (open) to cyclic (closed) processes, (iii) where waste from one industry is a raw material for another; (iv) an emphasis on harmonious integration between industrial activity and ecological systems. The idea is making industrial systems more efficient and sustainable (Garner \& Keolean, 1995; Ohnishi et al., 2012; Saraceni et al., 2013).

Given the current paradigms of Brazilian society, it can be said that it has been necessary for the country to undergo a process of sustainable development, since the literature shows that there are still many deficiencies in the Economic, Social and Environmental spheres (Tigre, 2006; Severo et al., 2015; Oliveira Brasil et al., 2016; Lucato et al,. 2017; Severo et al., 2017; Scur \& Barbosa, 2017).

The precarious reality of Brazilian industry in relation to competitiveness and innovation (pure or with technological increment) encouraged the development of this study. So, in order to find a path to encourage entrepreneurs to adopt environmental conservation practices, the main objective of this work was to respond the research guiding question: Does environmental conservation actions influences industrial competitiveness and innovation? 


\section{THEORETICAL FRAMEWORK}

In spite of efforts made aiming to create environmental awareness in society, literature has shown that only a small percentage of companies have a true commitment to this cause. Literature also shows that one of the main reasons for this attitude happens is due to, in addition to low awareness levels, the environmental conservation actions are not still considered determining factors for the stimulus of competitiveness and innovation.

Most part of publications found in literature are focused in validate the Porter hypothesis, seeking to fill the gaps and examine in which degree these relationships (innovation and competitiveness) occur (especially by means of econometric studies). Indeed, only a few works emphasize the ways such contributions occur, having importance in helping to understand entrepreneurs' awareness and vision.

Porter \& Van der Linde (1995) discuss a theory that later came to be known as the Porter Hypothesis. In this sense, Porter discusses the existence of strict environmental regulations in which companies can induce increased organizational efficiency and encourage innovations, helping to improve their competitiveness.

Esty \& Porter (1998) analyzed industrial environmental conservation actions in according to the concept of Industrial Ecology, and concluded that the Industrial Ecology approach mostly benefits companies seeking to improve their productivity and competitiveness. Still in according to the same authors, the systemic perspective of environmental conservation enabled by the Industrial Ecology can help companies to find paths in order to add value or reduce costs, both within their own production processes or throughout the whole supply chain

According to Ambec et al. (2011) Porter was an innovator by making such a claim and also by thinking in a way that opposed practically all the economists of that time, who believed that the existence of strict regulations decreases business possibilities, and consequently, the innovation and competitiveness of companies. Still according to the author's view, Porter hypothesis delineates that strict environmental regulations contribute to innovation and competitiveness, by strengthening the discovery and introduction of cleaner technologies with environmental focus (the innovation effect), making processes and products more acceptable therefore more efficient.

From the viewpoint of Frohwein \& Hansjürgens (2005) analyzed the specific case of environmental regulations applied to paper and chemistry industries in European Union. From another viewpoint, Wagner et al. (2002) and Wagner et al. (2003) published a study entitled "The Porter hypothesis revisited: a literature review of theoretical models and empirical tests". Such contributions provided a more comprehensive approach to the topic than debates addressed in literature until then, based on theoretical or empirical investigations regarding the Porter theory.

Similarly, Ambec et al. (2011) conducted a broad review of key theoretical and empirical insights presented in literature over the past twenty years, discussing the policy implications of these analyses and also contributing in other aspects.

In according to Epelbaum (2004) industrial environmental conservation actions influence competitiveness and innovation due two main factors: (i) tangible (for example, by increasing operational efficiency) and (ii) intangible (such as brand value and increasing company reputation). The author stresses out that the influence level of the first variable in relation to the second depends from the type of process, products or sectors involved and their environmental impacts, and also the degree of concern and environmental awareness of the parties (company and consumers). 
So, the implementation of an environmental management system according to ISO 14000 brings a series of competitive benefits, such as: cost reduction by reducing pollution and consumption of materials; in compliance with customer and investor criteria; improving overall management; and assisted image improvement (subject to the existence of other factors).

In addition to these findings, Young and Lustosa (2001) and Lustosa (2002) discuss other specific topics concerning this relationship, such as the impact of adopting environmental process technologies and its relationship within the Brazilian automotive sector. Their study describes the environmental performance and its relationship with competitiveness and innovation, in according to their findings; the performance of Brazilian sector is characterized by relative negligence on this subject, which eventually became one of the main causers of some of the most serious environmental problems. Withal, a new perspective has emerged in the nineties that associate environmental improvements with competitive gains.

Still according to Young and Lustosa (2001) and Lustosa (2002), an argument usually presented as a justification for lessening environmental control measures is that environmental costs reduce the competitiveness of national products in comparison to the countries of origin where these controls are non-existent. This standpoint is widely adopted in developing countries, being usually associated to the idea that the environmental issue is artificially imposed by developed countries based on the assumption that richer countries have already degraded their environment and now use the environmental issue to interfere in the economic development of poorer countries. Pollution is therefore considered unavoidable when trying to ensure industrial growth and, consequently, economic development.

In according to this dynamic perspective on the determining factors of competitiveness, it was observed that companies that access the international market show major concerns with environmental issues. Even more, data presented by the same authors seem to confirm that companies which engage $R \& D$ have greatest capacity to generate and adopt innovations, including environmental innovations. Process innovations aims to reduce environmental damage and environmental conservation strategies appear as factors that induce innovation, and are more clearly present in companies that attribute greater importance to their own $R \& D$ department.

Thus, justifications with practical implications for the conduction of this study were primarily based on two arguments: to encourage the implementation of environmental conservation actions in industries; to encourage (from a broader perspective) the promotion of sustainable development in developing countries by means of industrial environmental conservation actions resulting in increased competitiveness and innovation (aspects that are the driving force behind economic and social development) (Schumpeter, 1988; Freeman \& Soete, 1997). 


\section{RESEARCH METHODOLOGY}

The first viewpoint adopted in this study was a systematic review on international literature in order to have the knowledge basis on different research perspectives (Lakatos \& Marconi, 2001; Miguel, 2010). Additionally, a questionnaire was applied to a multi-sector group of 15 companies, in order to verify how these influences occur in practice, the results were useful to determine the differences between findings presented by literature and real-life events.

In this study, articles containing the research subject were obtained by searching the Scopus scientific database (containing about 19200 indexed journals). The searches were limited to studies published between 2009 and 2016, in order to gather the most recent information published on the subject. The Scopus database is considered the most relevant indexing platform for scientific papers in the world in terms of quantity and quality of indexed journals (Wang \& Waltman, 2016; Moed et al., 2016). The key-words used in the search platform are shown in Chart 1.

\section{Chart 1}

Keywords used in the bibliographical search

\begin{tabular}{|c|}
\hline Key-words \\
\hline Porter hypothesis \\
\hline Environmental Management Competitiveness relationship \\
\hline Environmental Management Innovation relationship \\
\hline ISO 14000 Competitiveness and Innovation \\
\hline Industrial Ecology Competitiveness \\
\hline Industrial Ecology Innovation \\
\hline Environmental Science \\
\hline Environmental Management \\
\hline
\end{tabular}

The key-words search was made by following the application of the Knowledge Development Constructivist-Process (ProKnow-C), developed by Ensslin et al., (2010) aiming to select the most relevant articles on the subject. This procedure consists of the following steps:

I.Selection of articles with titles aligned with the research topic;

II.Selection, among the articles obtained in the previous step, of articles with abstracts aligned with the research topic;

III.Selection of articles which the full content is aligned with the research topic

Articles regarding knowledge on the influence of industrial environmental conservation on competitiveness and innovation selected from the bibliographical portfolio were read and classified.

The bibliometric analysis (number of articles, authorship and temporal, regional and institutional distribution) of the surveyed articles is presented in the results section of this study. 


\section{Delimitation of Study Universe}

In order to identify a relation between the variables under study the following criteria for selection was adopted: companies with ISO-14000 certification were considered as having an indicative of corporate environmental responsibility and companies that are leaders in their segments or sectors due their competitiveness, which can be measured by the participation of these companies in their domestic markets (sectors). Furthermore, only companies classified as medium or large were selected. A criterion to defining companies with higher levels of innovation was not included due to the scarcity of data provided by the companies. Fifteen companies were chosen for this study being these located at a multi-sector industrial centre in the region of Campos Gerais - Paraná State, Southeast-Brazil.

\section{Questionnaire}

Given the nature of the research guiding question, the elaboration of a questionnaire that could reveal the perceptions of the managers of environmental departments in each company was considered the most appropriate way to conduct the investigation.

In spite of the existence of qualitative indicators that seek to measure corporate variables of environmental behaviour, competitiveness and innovation, the qualitative interrogation was considered more appropriate because the aim of this study was to know the means through which relationships occur and not the intensity of these relationships.

The manager responsible for the industrial environmental department of each company was chosen to respond to the questionnaire as this would be the person inside the company that most significantly centralizes information regarding the environment and its implications. The comparison between theoretical and practical results was based on convergence, divergence and/or complementarily in according to the ways in which environmental conservation actions influenced competitiveness and innovation.

\section{RESULTS AND DISCUSSION}

This section presents the bibliometric data concerning the articles used to create the bibliographical portfolio analyzed in research. This data available can be an important source to other researchers and policy promoters for the conduction of new studies and policies in this area thereby supporting this subject even more.

The search for articles with the selected key-words in the Scopus database between 2009 and 2016 (present) resulted in three hundred and eighty-two (382) articles. After application of the filtering criteria and considering access restrictions to the scientific platform, a total of thirty (30) articles were selected for the final bibliographical portfolio due to their significance for this study.

These articles were based on econometric or empirical research on companies of the second sector to show the main influence of industrial environmental conservation actions on competitiveness and innovation (especially innovations that strengthen competitiveness). Table 1 shows the number of selected articles according to the year of publication 
Table 1

Classification of studies included in the bibliographical portfolio per year

\begin{tabular}{c|c}
\hline Year & $\begin{array}{c}\text { Number of articles of } \\
\text { the bibliographical } \\
\text { portfolio }\end{array}$ \\
\hline 2009 & 1 \\
\hline 2010 & 3 \\
\hline 2011 & 5 \\
\hline 2012 & 4 \\
\hline 2013 & 7 \\
\hline 2014 & 7 \\
\hline 2015 & 2 \\
\hline 2016 & 1 \\
\hline
\end{tabular}

Table 1 shows an irregular trend concerning the number of published articles on the investigated subject throughout the years. The thirty articles analyzed in bibliographical research were published in twenty-six different journals, among which are listed in Table 2.

Table 2

Classification of studies included in the bibliographical portfolio per journal

\begin{tabular}{l|c}
\hline \multicolumn{1}{c|}{ Journal } & $\begin{array}{c}\text { Number of articles in } \\
\text { the bibliographical } \\
\text { portfolio }\end{array}$ \\
\hline Journal of Cleaner Production & 3 \\
\hline Business Strategy and the Environment & 2 \\
\hline Transportation Research & 2 \\
\hline Contemporary Economic Policy & 1 \\
\hline $\begin{array}{l}\text { Journal of Economics \& Management } \\
\text { Strategy }\end{array}$ & 1 \\
\hline Indian Growth and Development Review & 1 \\
\hline Science Technology Society & 1 \\
\hline Industry and Innovation & 1 \\
\hline Oxford Bulletin of Economics and Statistics & 1 \\
\hline Resource and Energy Economics & 1 \\
\hline The World Economy & 1 \\
\hline Environmental Policy and Governance & 1 \\
\hline Ecological Economics & 1 \\
\hline Journal of Applied Economics & 1 \\
\hline Sustainability & 1 \\
\hline Energy Innovation & 1 \\
\hline Applied Economics & 1 \\
\hline Energy Economics & 1 \\
\hline International Journal of Production & 1 \\
Economics & 1 \\
\hline International Journal of & 1 \\
Management & 1 \\
\hline $\begin{array}{l}\text { Accounting, Auditing \& } \\
\text { Expert Systems with Applications }\end{array}$ \\
\hline Human Factors and Ergonomics & 1 \\
\hline Manufacturing \& Service Industries & 1 \\
\hline Resources, Conservation and Recycling & 1 \\
\hline Journal Plos One & 1 \\
\hline Science of the Total Environment & 1 \\
\hline
\end{tabular}


This list shows that the Journal of Cleaner Production published the greatest number of articles in the bibliographical portfolio on the requested subject, with three articles, followed by Business Strategy and the Environment and Transportation Research, with two articles each. The remaining journals have only published one article each.

Table 3 shows the classification of studies included in the bibliographical portfolio per authors that have contributed.

\section{Table 3}

\section{Classification of studies included in the bibliographical portfolio per author}

\begin{tabular}{|c|c|c|c|}
\hline Author & $\begin{array}{c}\text { Number of articles in } \\
\text { the bibliographical } \\
\text { portfolio }\end{array}$ & Author & $\begin{array}{c}\text { Number of articles in } \\
\text { the bibliographical } \\
\text { portfolio }\end{array}$ \\
\hline Chiang-Ping Chen & 2 & K. Narayanan & 1 \\
\hline Chwen Sheu & 2 & Keng-Boon Ooi & 1 \\
\hline Klaus Rennings & 2 & Kristina Söderholm & 1 \\
\hline Akihiro Otsuka & 1 & Makiko Nakano & 1 \\
\hline Alain Yee-Loong Chong & 1 & Marcus Wagner & 1 \\
\hline Aldónio Ferreira & 1 & Md. Uzzal Hossain & 1 \\
\hline Alonso Aguilar-Ibarra & 1 & Mika Goto & 1 \\
\hline Andrea Bikfalvi & 1 & Nada Smigic & 1 \\
\hline Andreja Rajkovic & 1 & Nick Johnstone & 1 \\
\hline Ann-Kristin Bergquist & 1 & Nikola Tomic & 1 \\
\hline Armando Sanchez-Vargas & 1 & Nivedita Dutta & 1 \\
\hline Bayu Hendro & 1 & Paul Lanoie & 1 \\
\hline Carly Moulang & 1 & Radomir Radovanovic & 1 \\
\hline Chen-Lung Yang & 1 & Ricardo Mansilla-Sanchez & 1 \\
\hline Chih-Hai Yang & 1 & Roberta de Santis & 1 \\
\hline Chi Sun Poon & 1 & Roberto da Luz Neto & 1 \\
\hline Christian Remmer & 1 & Rodolfo de Castro & 1 \\
\hline Christopher Seow & 1 & Sai Ho Chung & 1 \\
\hline Clandia Maffini Gomes & 1 & Sandwip K. Das & 1 \\
\hline Claudia Ghisetti & 1 & Seda Meyveci Doganay & 1 \\
\hline Colin C. J. Cheng & 1 & Selin Sayek & 1 \\
\hline Dietrich Earnhart & 1 & Shu-Ping Lin & 1 \\
\hline Dylan R. Rassier & 1 & Stanley Kam Sing Wong & 1 \\
\hline Emiko Inoue & 1 & Stefan Ambec & 1 \\
\hline Fatma Taskin & 1 & Thomas Ziesemer & 1 \\
\hline Felix Groba & 1 & Toshi A. Arimura & 1 \\
\hline Fiona Lettice & 1 & Toshivuki Sueyoshi & 1 \\
\hline Flávia Luciane Scherer & 1 & Todd BenDor & 1 \\
\hline Frederic Marimon & 1 & T. William Lester & 1 \\
\hline Hing Kai Chan & 1 & Tzu-Yun Chiou & 1 \\
\hline Ilija Djekic & 1 & $\begin{array}{c}\text { Uiara Gonçalves de } \\
\text { Menezes }\end{array}$ & 1 \\
\hline Indrani Roy Chowdhury & 1 & Voon-Hsien Lee & 1 \\
\hline Isak Kruglianskas & 1 & Xi Yang & 1 \\
\hline Jérémy Laurent-Lucchetti & 1 & Ya-Hui Chan & 1 \\
\hline Joseph Llach & 1 & Yang Yao & 1 \\
\hline \multirow[t]{2}{*}{ Jinglei Gao } & 1 & Yu-Hsuan Tseng & 1 \\
\hline & 1 & Zengwei Yuan & 1 \\
\hline
\end{tabular}


A total of seventy-three individuals authored or co-authored the thirty selected articles, most of which (eighty) wrote only one article. Emphasizing those three authors published two articles each. The number of authors was greater than the number of articles because most articles were written by more than one author.

Table 4 shows the classification studies per institutions and countries that supported the publication of studies.

Table 4

Classification of studies included in the bibliographical portfolio per institution/country

\begin{tabular}{|c|c|c|}
\hline Institution & $\begin{array}{l}\text { Country of } \\
\text { institution }\end{array}$ & $\begin{array}{l}\text { Number of articles in } \\
\text { the bibliographical } \\
\text { portfolio }\end{array}$ \\
\hline Centre for European Economic Research & Germany & 2 \\
\hline Chung Hua University & Taiwan & 2 \\
\hline Kansas State University & USA & 2 \\
\hline Hong Kong Polytechnic University & Hong Kong & 2 \\
\hline Bilkent University & Turkey & 1 \\
\hline Boureal of Economic Analysis & USA & 1 \\
\hline Cardiff University & USA & 1 \\
\hline Central Research Institute of Electric Power Industry & Japan & 1 \\
\hline Chang Jung Christian University & Taiwan & 1 \\
\hline German Institute of Economic Research & Germany & 1 \\
\hline Ghent University & Belgium & 1 \\
\hline HEC Montreal Economics & Canada & 1 \\
\hline Indian Institute of Technology Bombay & India & 1 \\
\hline Jamia Millia Islamia University & India & 1 \\
\hline JANA (NAB Group) & Australia & 1 \\
\hline Jawaharlal Nehru University & India & 1 \\
\hline Johns Hopkins University & USA & 1 \\
\hline Kyoto University & Japan & 1 \\
\hline Linton University College & Malaysia & 1 \\
\hline Luleå University of Technology & Sweden & 1 \\
\hline Monash University & Australia & 1 \\
\hline Nagova University & Japan & 1 \\
\hline Hong Kong University of Science and Technology & Hong Kong & 1 \\
\hline National Autonomous University of Mexico & Mexico & 1 \\
\hline National Central University - Taiwan & Taiwan & 1 \\
\hline National Cheng Kung University & Taiwan & 1 \\
\hline National Kaohsiung First University of Science \& Technol. & Taiwan & 1 \\
\hline New Mexico Institute of Mining \& Technology & USA & 1 \\
\hline OECD Environment Directorate & France & 1 \\
\hline Peking University & China & 1 \\
\hline Santa Maria Federal University & Brazil & 1 \\
\hline
\end{tabular}




\begin{tabular}{c|c|c}
\hline University of São Paulo & Brazil & 1 \\
\hline Technical University of Munich & Germany & 1 \\
\hline Toulose School of Economics & France & 1 \\
\hline Umeå University & Sweden & 1 \\
\hline Universitat de Girona & Spain & 1 \\
\hline Universitat Internacional de Catalunya & Spain & 1 \\
\hline Université Louis Pasteur & France & 1 \\
\cline { 2 - 3 } & Malaysia & 1 \\
\hline Universiti Tunku Abdul Rahman & Germany & 1 \\
\hline University of Alsburg & Serbia & 1 \\
\hline University of Belgrade & Switzerland & 1 \\
\hline University of Bern & Italy & 1 \\
\hline University of Bologna & UK & 1 \\
\hline University of Chester & UK & 1 \\
\hline University of East Anglia & USA & 1 \\
\hline University of Baltimore & USA & 1 \\
\hline University of Kansas & Australia & 1 \\
\hline University of Newcastle & UK & 1 \\
\hline University of Nottingham & Italy & 1 \\
\hline Universty of Roma La Sapienza & Japan & 1 \\
\hline Waseda University & Taiwan & 1 \\
\hline William E. Connor Group & China & 1 \\
\hline Nanjing University & USA & 1 \\
\hline University of North Carline & & \\
\hline
\end{tabular}

From the fifty-four institutions which contributed to the authorship or co-authorship, among the thirty articles included in the bibliographical portfolio, only four institutions contributed with the publication of two articles and the remaining institutions achieved one article each. The number of institutions that contributed with the publication of articles in the portfolio was greater than the number of articles because most articles were written in partnership between authors of several institutions. Table 5 shows the countries of origin of the published articles.

Table 5

\section{Classification of studies included in the bibliographical portfolio per country}

\begin{tabular}{c|c}
\hline Country & $\begin{array}{l}\text { Number of articles from } \\
\text { bibliographical portfolio }\end{array}$ \\
\hline USA & 7 \\
\hline Germany & 5 \\
\hline Taiwan & 5 \\
\hline China & 3 \\
\hline Australia & 2 \\
\hline France & 2 \\
\hline India & 2 \\
\hline Italy & 2 \\
\hline Japan & 2 \\
\hline UK & 2 \\
\hline Hong Kong & 2 \\
\hline Brazil & 1 \\
\hline Canada & 1 \\
\hline Spain & 1 \\
\hline Belgium & 1 \\
\hline Malaysia & 1 \\
\hline Mexico & 1 \\
\hline Serbia & 1 \\
\hline Sweden & 1 \\
\hline Switzerland & 1 \\
\hline Turkey & 1 \\
\hline &
\end{tabular}


As expected, most published articles were from developed countries which have emphatically contributed more to science in recent years. Table 6 shows that the influence of industrial environmental conservation actions on competitiveness and innovation were observed in thirty articles.

Table 6

Ways that industrial environmental conservation actions influence competitiveness and innovation according to the knowledge basis present in literature

\begin{tabular}{|c|c|}
\hline Influences & $\begin{array}{l}\text { Number of companies that } \\
\text { mentioned this influence }\end{array}$ \\
\hline Ways that influence occurs & Authors who contributed \\
\hline Cost and loss reduction & $\begin{array}{l}\text { Wagner (2009); Ferreira et al. (2010); Rennings and } \\
\text { Rammer (2011); Lanoie et al. (2011); Dutta and } \\
\text { Narayanan (2011); Chowdhury and Das (2011); } \\
\text { Ziesemer (2013); Inoue et al. (2013); Wong (2013); } \\
\text { Sanchez-Vargas et al. (2013); Cheng et al. (2014); Lee } \\
\text { et al. (2014); Ghisetti et al. (2014); Jinglei Gao et al. } \\
\text { (2015). }\end{array}$ \\
\hline $\begin{array}{l}\text { Implementation of continued improvements (that can } \\
\text { be considered the foundation of all the above- } \\
\text { mentioned actions) }\end{array}$ & Yang et al. (2010); Todd BenDor et al (2015). \\
\hline $\begin{array}{l}\text { Innovation of the company management system } \\
\text { (organizational innovations) - changes in company } \\
\text { management as a determining factor of company } \\
\text { performance }\end{array}$ & Cheng et al. (2014) \\
\hline $\begin{array}{l}\text { Development of new products where environmental } \\
\text { risk or impact is minimized - Green Research and } \\
\text { Development }\end{array}$ & $\begin{array}{l}\text { Wagner (2009); Rennings and Rammer (2011); } \\
\text { Ziesemer (2013); Inoue et al. (2013); Wong (2013); } \\
\text { Söderholm and Bergquist (2013); Cheng et al. (2014); } \\
\text { Lee et al. (2014) }\end{array}$ \\
\hline $\begin{array}{l}\text { Increased operational/production efficiency - process } \\
\text { innovations to meet environmental requirements that } \\
\text { allow increased operational efficiency, such as } \\
\text { through task and teamwork integration and other } \\
\text { aspects or tools of Environmental Management. }\end{array}$ & $\begin{array}{l}\text { Llach et al. (2012); Söderholm and Bergquist (2013); } \\
\text { Goto et al. (2014); Ghisetti et al. (2014); Lee et al. } \\
\text { (2014) }\end{array}$ \\
\hline $\begin{array}{l}\text { Increased productivity - process innovations to meet } \\
\text { environmental requirements and that allow increased } \\
\text { productivity }\end{array}$ & Yang et al. (2012); Sanchez-Vargas et al. (2013) \\
\hline $\begin{array}{l}\text { Improved company image in the market - increased } \\
\text { market participation of certified companies }\end{array}$ & $\begin{array}{l}\text { Yang and Yao (2012); Gomes et al. (2013); Djekic et } \\
\text { al. (2014); Wagner (2009). }\end{array}$ \\
\hline $\begin{array}{l}\text { Revenue with by-products - such as revenue } \\
\text { generation with recyclables or waste considered by } \\
\text { Lee at al. (2014) as a way to recover investments } \\
\end{array}$ & $\begin{array}{l}\text { Rennings and Rammer (2011); Lee et al. (2014), Md. } \\
\text { Uzzal Hossain et al (2016). }\end{array}$ \\
\hline $\begin{array}{l}\text { Non-generation of export barriers given that, for } \\
\text { example, the company meets ISO } 14000 \text { certification } \\
\text { requirements }\end{array}$ & De Santis (2012); Groba (2014); Doganai et al. (2014) \\
\hline
\end{tabular}


Table 7 shows the responses of the questionnaire applied to the 15 investigated companies:

Table 7

Ways that industrial environmental conservation actions influence competitiveness and innovation according to knowledge basis presented by the multi-sector group of companies studied

\begin{tabular}{c|c}
\hline Cost and loss reduction & 4 \\
\hline $\begin{array}{c}\text { Implementation of continued improvements (that can } \\
\text { be considered the foundation of all the above- } \\
\text { mentioned actions) }\end{array}$ & 10 \\
\hline $\begin{array}{c}\text { Imnovation of the company management system } \\
\text { (organizational innovations) - changes in company } \\
\text { management as a determining factor of company } \\
\text { performance }\end{array}$ & 13 \\
\hline $\begin{array}{c}\text { Developments of new products were environmental } \\
\text { risks or impact can be minimized and correct } \\
\text { selection of material to be used in the product. }\end{array}$ & 12 \\
\hline $\begin{array}{c}\text { Increased productivity - Increased } \\
\text { operational/production efficiency }\end{array}$ & 8 \\
\hline Revenue generation with recyclables & 12 \\
\hline Non-generation of export barriers & 11 \\
\hline Improved company image in the market & 11 \\
\hline
\end{tabular}

The knowledge basis obtained from systematic review (theoretical results) reinforced the responses of companies obtained from questionnaire (practical results). So it is clear that industrial environmental conservation actions have influence on competitiveness and innovation, mainly occurring through continued improvements, innovating company management system, developing new products with environmental risk or impact is minimized, processing innovations to meet environmental requirements thereby allowing to increase the operational efficiency, processing innovations meeting environmental requirements allowing to increase the productivity, revenue generation with recyclables or wastes, non-generating export barriers, and resulting in costs and losses reduction thereupon improving the company image in the market.

\section{CONCLUSION}

Results showed a complementarily and convergence of knowledge, since results obtained from systematic review partly incorporated the responses from questionnaire, so results showed that in practice companies support the theoretical base established by the Porter hypothesis.. It can be seen that industrial environmental conservation actions have influence on competitiveness and innovation, thus answering the guiding question of this study. Therefore it is important to encouraging companies to adopt greener practices and processes, in order to maximize their profits in a sustainable way, a main objective in current business market and also one encourager for the occurrence of organizational changes. 


\section{REFERENCES}

Andrade, R.O.B.; Tachizawa, T., Carvalho, A.B. (2000). Gestão ambiental: enfoque estratégico aplicado ao desenvolvimento sustentável. São Paulo: Makron Books, p. 206.

Almeida, C.M.V.B.; Gianetti, B. (2006). Ecologia Industrial: conceitos, ferramentas e aplicações. São Paulo: Edgard Blücher, p. 128.

Bendor, T.; Lester, T.W.; Livengood, A.; Davis, A.; Yonavjac, L. (2015). Estimating the Size and Impact of the Ecological Restoration Economy. Plos One Journal, 10(6): e0128339.

Cheng, C. C. J.; Yang, C. L.; Sheu, C. (2014). The link between eco-innovation and business performance: a Taiwanese industry context. Journal of Cleaner Production, 64: 81-90.

Chiou, T. Y.; Chan, H. K.; Lettice, F.; Chung, S. H. (2011). The influence of greening the suppliers on environmental performance and competitive advantage on Taiwan. Transportation Research Part E, 47:822-836.

Chowdhury, I. R.; Das, S. K. (2011). Environmental regulation, green R\&D and the Porter hypothesis. Indian Growth and Development Review, 4(2):142-152.

Costa, M. M. Princípios de Ecologia Industrial aplicados a sustentabilidade ambiental e aos sistemas de produção de aço. 2002. $271 \mathrm{f}$. Tese (Doutorado em Ciências em Planejamento Energético) - Programa de Pós Graduação em Engenharia da Universidade Federal do Rio de Janeiro (UFRJ).

De Santis, R. (2012). Impact of environmental regulations on trade in the main EU countries: conflict or synergy? The World Economy, 93:1-24.

Djekic, I.; Rajkovic, A.; Tomic, N.; Smigic, N.; Radovanovic, R. (2014). Environmental management effects in certified Serbian food companies. Journal of Cleaner Production, 76:196-199, 2014.

Doganay, S. M.; Sayek, S.; Taskin, F. (2014). Is environmental efficiency trade inducing or trade hindering? Energy Economics, 44:340-349.

Dutta, N.; Narayanan, K. (2011). Impact of environmental regulation on Technical Efficiency: a study of Chemical Industry in and around Mumbai. Science, Technology \& Society, 16(3):333350 .

Eidat, Y.; Kelly, A.; Roche, F.; Eyadat, F. (2008). Green and Competitive? An empirical test of the mediating role of environmental innovation strategy. Journal of World Business, 43, p. 133. 
Esty, D. C.; Porter, M. (1998). Industrial Ecology and Competitiveness: strategic implications for the firm. Journal of Industrial Ecology, 2(1):35-43.

Epelbaum, M. (2004). A influência da Gestão Ambiental na competitividade e no sucesso empresarial. São Paulo, SP. Dissertação (Mestrado em Engenharia de Produção) - Escola Politécnica da USP.

Ferreira, A.; Moulang, C.; Hendro, B. (2010). Environmental management accounting and innovation: an exploratory analysis. Accounting, Auditing \& Accountability Journal, 23(7):920-948.

Freeman, C.; Soete, L. (1997). The economics of industrial innovation. $3^{\mathrm{a}}$ ed. London/Washington: Pinter Publishers, p. 470.

Frohwein, T.; Hansjürgens, B. (2005). Chemicals regulation and the Porter hypothesis: a critical review of the new European chemicals regulation. Journal of Business Chemistry, 2(1):19-36.

Gao, J.; Yuan, Z.; Liu, X.; Xia, X.; Huang, X.; Dong, Z. (2015). Improving air pollution control policy in China - A perspective based on cost-benefit analysis. Science of Total Environment, 543(Part A):307-314.

Ghisetti, C.; Rennings, K. (2014). Environmental innovations and profitability: how does it pay to be green? An empirical analysis on the German innovation survey. Journal of Cleaner Production, 75:106-117.

Gomes, C, M. Scherer, F. L.; Menezes, U. G.; Neto, R. L. (2013). Strategies of sustainable management and business performance: an analysis in innovative companies. International Journal of Innovation Management, 17(5). doi: 10.1142/S1363919613500266.

Goto, M.; Otsuka, A.; Sueyoshi, T. (2014). DEA(Data Envelopment Analysis) assessment of operational and environmental efficiencies on Japonese regional industries. Energy, 66:535-549.

Groba, F. (2014). Determinants of trade with solar energy technology components: evidence on the Porter hypothesis? Applied Economics, 46(5):503- 526, 2014.

Hossain, U.; Poon, C.S.; Lo, I.M.C.; Cheng, J.C.P. (2016). Comparative environmental evaluation of aggregate production from recycled waste materials and virgin sources by LCA. Resources, Conservation and Recycling, 109:67-77.

Inoue, E.; Arimura, T. H.; Nakano, M. (2013). A new insight into environmental innovation: does the maturity of environmental management systems matter? Ecological Economics, 94:156-163.

Lanoie, P.; Laurent-Lucchetti, J.; Johnstone, N.; Ambec, S. (2011). Environmental Policy, Innovation and Performance: new insights on the Porter hypothesis. Journal of Economics \& Management Strategy, v. 20(3):803-842.

Lee, V. H. Ooi, K. B.; Chong, A. Y. L. ; Seow, C. (2014). Creating technological innovation via green supply chain management: an empirical analysis. Expert Systems with Applications, 41:6983-6994. 
Li, Y. R. (2009). The technological roadmap of Cisco's business ecosystem. Technovation, 29(5):379-386, 2009.

Llach, J.; Castro, R.; Bikfalvi, A.; Marimon, F. (2012). The relationship between environmental management systems and organizational innovations. Human Factors and Ergonomics in Manufacturing \& Service Industries, 22(4):307-316, 2012.

Lucato, W.C.; Costa, E.M.; Oliveira Neto, G.C. (2017). The environmental performance of SMEs in the Brazilian textile industry and the relationship with their financial performance. Journal of Environmental Management, 1-7.

Lustosa, M. C. J. (2002). Meio Ambiente, Inovação e Competitividade na Indústria Brasileira: a cadeia produtiva do petróleo. $246 \mathrm{f}$. Tese (Doutorado em Economia) - Instituto de Economia da Universidade Federal do Rio de Janeiro (UFRJ). Rio de Janeiro - RJ.

Moed, H.F.; Bar-Ilan, J.; Halevi, G. (2016). A new methodology for comparing Google Scholar and Scopus. Journal of Infometrics, 10(2): 533-551.

Oliveira Brasil, M.V.; Sá De Abreu; M.C.; Silva Filho, J.C.; Leocádio, A.U. (2016). Relationship between eco-innovations and the impact on business performance: an empirical survey research on the Brazilian textile industry. Environmental Management, 51: 276-287.

Porter, M.; Van Der Linde, C. (1995). Towards a new conception of the EnvironmentCompetitiveness relationship. Journal of Economic Perspectives, 9(4):95-118.

Rennings, K.; Rammer, C. (2011). The impact of regulation-driven environmental innovation on innovation success and firm performance. Industry and Innovation, 18(3):255-283.

Sanchez-Vargas, A.; Mansilla-Sanchez, R.; Aguilar-Ibarra, A. (2013). An empirical analysis of the nonlinear relationship between environmental regulation and manufacturing productivity. Journal of Applied Economics, 16(2):357-372.

Schumpeter, J. (1988). Teoria do desenvolvimento econômico. Edição Brasileira. São Paulo: Editora Nova Cultural, p. 534.

Scur, G.; Barbosa, M.E. (2017). Green supply chain management practices: Multiple case studies in the Brazilian home appliance industry. Journal of Cleaner Production, 141: 12931302.

Seiffert, M. E. B. (2011). Gestão Ambiental: instrumentos, esferas de ação e educação ambiental. São Paulo: Atlas, p. 328.

Severo, E.A.; Guimarães, J.C.F.; Dorion, E.C.H.; Nodari, C.H. (2015). Cleaner production, environmental sustainability and organizational performance: an empirical study in the Brazilian Metal-Mechanic industry. Journal of Cleaner Production, 96: 118-195. 
Severo, E.A.; Guimarães, J.C.F.; Dorion, E.C.H. (2017). Cleaner production and environmental management as sustainable product innovation antecedents: A survey in Brazilian industries. Journal of Cleaner Production, 142: 87-97.

Söderholm, K.; Bergquist, A. K. (2013). Growing green and competitive - a case study of a Swedish pulp mill. Sustainability, 5:1789-1805.

Tigre, P. B. (2006). Gestão da Inovação: a economia da tecnologia no Brasil. Rio de Janeiro: Elsevier, $282 \mathrm{p}$.

Vachon, S.; Klassen, R. D. (2008). Environmental management and manufacturing performance: The role of collaboration in the supply chain. International Journal of Production Economics, 111(2): 299315.

Van Bellen, H. M. (2006). Indicadores de sustentabilidade: uma análise comparativa. Rio de Janeiro: Editora FGV, p. 256.

Wagner, M. (2003). The Porter Hypothesis revisited: a literature review of theoretical models and empirical tests. Publication of the Centre for Sustainability Management (CSM) - University of Lueneburg, p. 50.

Wagner, M. (2009). Innovation and competitive advantages from the integration of strategicaspects with social and environmental management in European firms. Business Strategy and the Environement, 18, 291-306.

Wagner, M.; Phu, N. V.; Azomahou, T.; Wehrmeyer, W. (2002). The relationship between environmental and economic performance of firms: an empirical analysis of the European paper industry. Corporate Social Responsibility and Environmental Management, 9(3):133-146.

Wang, Q.; Waltman, L. (2016). Large-scale analysis of the accuracy of the journal classification systems of Web of Science and Scopus. Journal of Infometrics, 10(2): 347-364, 2016.

Wong, S. K. S. (2013). Environmental requirements, knowledge sharing and green innovation: empirical evidence from the electronics industry in China. Business Strategy and the Environment, $22,321-338$.

Yang, C. H.; Tseng, Y. H.; Chen, C. P. (2012). Environmental regulations, induced R\&D, and productivity: evidence from Taiwan's manufacturing industries. Resource and Energy Economics, 34:514-532.

Yang, C. L.; Lin, S. P.; Chan, Y. H.; Sheu, C. (2010). Mediated effect of environmental management on manufacturing competitiveness: an empirical study. International Journal of Production Economics, 123, 210-220. 
Yang, C. S.; Lu, C. S.; Haider, J. J.; Marlow, P. B. (2013). The effect of green supply chain management on green performance and firm competitiveness in the context of container shipping on Taiwan. Transportation Research Part E, 55:55- 73.

Yang, X.; Yao, Y. (2012). Environmental compliance and firm performance: evidence from China. Oxford Bulletin of Economics and Statistics, 74(3):397-524.

Young, C. E. F.; Lustosa, M. C. J. (2001). Meio Ambiente e Competitividade na Indústria Brasileira. Revista de Economia Contemporânea, v. 5, edição especial, 231-259.

Ziesemer, T. (2013). A knowledge based view of the Porter hypothesis. Environmental Policy and Governance, 23:193-208. 